\title{
KEARIFAN LOKAL DALAM UNGKAPAN TRADISIONAL: MEMBACA ULANG KARAKTERISTIK MASYARAKAT PASAMAN BARAT
}

\author{
LOCAL WISDOM AT TRADITIONAL EXPRESSIONS: \\ READ REPEATED CHARACTER BY PEOPLE OF PASAMAN BARAT
}

\author{
Hasanadi \\ Balai Pelestarian Nilai Budaya Sumatera Barat \\ Jl. Raya Belimbing No.16 A, Kuranji Kota Padang \\ E-mail: hasanassyahda@yahoo.co.id \\ Naskah diterima 4 Mei 2018, diterima setelah perbaikan 9 Mei 2018, \\ disetujui untuk dicetak 31 Mei 2018
}

\begin{abstract}
Abstrak
Melalui tulisan ini diketengahkan bahasan tentang karakteristik masyarakat Minangkabau di Pasaman Barat Provinsi Sumatera Barat, yaitu sebagai bagian dari kearifan lokal (local wisdom). Hal ini direfleksikan melalui berbagai ungkapan tradisional Minangkabau yang terdapat di daerah ini. Ungkapan tradisional dimaksud adalah : (1) Ungkapan mandapek raso kailangan; (2) Ungkapan sairiang batuka jalan sarupo balain sabuik; (3) Ungkapan jorong batakok tanun baguluang; (4) Ungkapan mamak bapisau tajam kamanakan balihia gantiang; dan (5) Ungkapan maampang ndak sampai ka subarang mandindiang ndak sampai ka langik. Dengan menggunakan pendekatan hermeneutik disimpulkan bahwa kelima ungkapan berbicara tentang berbagai karakteristik masyarakat Minangkabau di Pasaman Barat, di antaranya responsif, menghargai perbedaan, profesional, bertanggung jawab, proporsional, berpikir jauh ke depan serta toleran.
\end{abstract}

Kata kunci : Ungkapan tradisional, karakteristik, masyarakat Pasaman Barat.

\begin{abstract}
Through this paper, a discussion about the characteristics of the Minangkabau community in West Pasaman, West Sumatra Province, is presented as part of the local wisdom. It is reflected through various traditional Minangkabau expressions found in this area. These traditional expressions are: (1) the phrase mandapek raso kailangan; (2) The expression of sairiang batuka, sarupo road, balain sabuik; (3) The expression of jorong batakok tanun baguluang; (4) The phrase mamak is a sharp blade of the kamanakan balihia gantiang; and (5) the expression is not until the mandindiang is not arrived at. Using a hermeneutic approach, it was concluded that the five expressions are about various characteristics of Minangkabau people in Pasaman Barat, including responsiveness, respect for differences, professionalism, responsibility, proportionality, forward thinking and tolerance.
\end{abstract}

Keywords: traditional expressions, characteristics, people of West Pasaman. 


\section{PENDAHULUAN}

Objek kajian yang dibahas dalam tulisan ini ungkapan tradisional Minangkabau yang ditemukenali penggunaannya pada masyarakat Kecamatan Pasaman Kabupaten Pasaman Barat Provinsi Sumatera Barat. Secara khusus dokumentasi terhadap teks ungkapan tradisional tersebut dilakukan di 3 (tiga) nagari yang terdapat di Kecamatan Pasaman Kabupaten Pasaman Barat. Kajian terhadap ungkapan tradisional Minangkabau sebagaimana digunakan oleh masyarakat Kecamatan Pasaman penting untuk dilakukan. Pertama, kajian ini menjadi langkah strategis sekaligus antisipatif dalam upaya melahirkan satu bentuk dokumentasi teks ungkapan tradisional, sehingga menjawab persoalan terkondisinya ungkapan tradisional tersebut berada dalam kepunahan. Kedua, sebagaimana disampaikan oleh Musrizal Katik Jo Mangkuto (wawancara tanggal 12 Mei 2016) penelitian terhadap ungkapan tradisional Minangkabau menjadi penting berkenaan dengan perlunya pewarisan nilai-nilai kearifan lokal yang terdapat dalam setiap ungkapan kepada masyarakat, khususnya kepada generasi muda. Menurutnya, generasi muda di Pasaman Barat umumnya perlu memahami bentuk-bentuk pengetahuan tradisional, kebijaksanaan-kebijaksanaan, serta sikap budaya masyarakat Minangkabau sebagaimana terdapat pada berbagai ungkapan tradisional, terutama dalam upaya penguatan karakter keminangkabauan mereka.

Penguatan karakter generasi muda melalui pewarisan kearifan lokal seperti halnya terdapat pada ungkapan tradisional Minangkabau berhadapan dengan berbagai kendala dan tentangan. Menurut Yul Hendri Dt. Putiah (wawancara tanggal 13 Mei 2016), tantangan terbesar yang dihadapi dalam usaha pewarisan tersebut berasal dari perkembangan serta kemajuan teknologi informasi. Dekatnya kehidupan generasi muda dengan berbagai teknologi informasi seperti handphone telah berdanpak pada semakin jaraknya mereka dengan khasanah budaya lokal semisal ungkapan tradisional. Di lain pihak, sebagian pemangku adat di Kecamatan Pasaman pun memiliki keterbatasan pengetahuan tentang nilai budaya ungkapan tradisional, di samping adanya persoalan waktu dan kesempatan untuk melakukan proses pembelajaran serta pewarisan kepada generasi muda. Pada konteks pola hubungan sosial budaya yang lebih sempit, misalnya pola hubungan antara mamak dan kemenakan, tuntutan zaman telah menggiring untuk terciptanya jarak antara seorang mamak dengan kemenakannya disebabkan oleh keterbatasan pengetahuan, waktu, dan kesempatan tersebut.

Sebaliknya, secara normatif kepedulian para tokoh masyarakat yang tergabung dalam struktur Karapatan Adat Nagari (KAN) di Kecamatan Pasaman, dinilai mampu mendorong munculnya ide, gagasan serta kreatifitas sosial yang mendukung berlanjutnya proses pewarisan nilai budaya ungkapan tradisional kepada generasi muda. Sikap terorganisir anggota Karapatan Adat Nagari (KAN) yang memahami secara baik nilai budaya ungkapan tradisional, melalui pemunculan berbagai kegiatan sosial budaya, diharapkan mampu mewarnai keseharian generasi muda. Konsekuensinya adalah, nilai budaya ungkapan tradisional terwariskan melalui berbagai kegiatan tersebut, sehingga usaha pembentukan karakter generasi muda berbasis nilai budaya ungkapan tradisional Minangkabau terus berlanjut. Berkaitan dengan itu, tulisan ini diharapkan memperkaya khasanah pengetahuan pemangku adat serta tokoh masyarakat lainnya di Kecamatan Pasaman dalam upaya memahami nilai budaya yang terdapat pada berbagai ungkapan tradisional Minangkabau yang terdapat di daerah ini. Pertanyaan penting yang ingin dijawab melalui tulisan 
ini adalah, bagaimana karakteristik masyarakat Minangkabau sebagaimana terefleksi melalui teks ungkapan tradisional yang diapresiasi oleh masyarakat Kecamatan Pasaman?. Pengetahuan serta pemahaman terhadap karakteristik masyarakat Minangkabau tersebut menjadi relevan dalam mewujudkan harmoni di setiap kegiatan sosial budaya yang berlangsung serta dimaksudkan sebagai media pewarisan nilai budaya kepada masyarakat dan generasi muda.

\section{METODE PENELITIAN}

Istilah "karakter" (character) dalam bahasa Inggris berasal dari bahasa Yunani yang artinya "membentuk ke dalam tulisan" (to inscribe). Hal ini mencerminkan bahwa karakter bukanlah sesuatu yang ada secara alamiah/dibawa sejak lahir, melainkan suatu proses bentukan yang dipengaruhi oleh berbagai masukan pertemanan, sekolah, tempat pekerjaan, dan seterusnya (Hadi dkk, 2005:9).

Karakter juga dibentuk oleh kebudayaan. Melalui perspektif kebudayaan dapat dipahami bahwa kearifan lokal, di dalamya terdapat nilai budaya, diciptakan guna membentuk karakter masyarakat pemilik kebudayaan tersebut. Kearifan lokal sekaligus terus dikembangkan dan dipertahankan oleh masyarakat kebudayaan tertentu serta karena kemampuannya masyarakat tersebut dapat bertahan serta menjadikan kearifan lokal tersebut sebagai pedoman dalam pembentukan karakter masyarakat. Pada konteks pembentukan karakteristik masyarakat budaya tersebut, Sibarani (2016:437), menawarkan lima dimensi kultural tentang kearifan lokal, yaitu pengetahuan lokal, budaya lokal, keterampilan lokal, sumber daya lokal, dan proses sosial lokal. Pengetahuan lokal bertautan dengan data dan informasi tentang karakter keunikan lokal serta pengetahuan dan pengalaman masyarakat dalam menghadapi masalah serta solusinya. Budaya lokal terkait dengan unsur-unsur kebudayaan yang telah terpola dan dijadikan sebagai tradisi. Keterampilan lokal berkaitan dengan keahlian masyarakat untuk memanfaatkan pengetahuan yang diperoleh. Sumberdaya lokal berkenaan dengan ketersediaan akses, potensi dan sumber lokal yang unik. Proses'sosial lokal berbicara tentang bagaimanakah masyarakat tertentu menjalankan fungsi-fungsinya, sistem tindakan sosial yang dilakukan, tata hubungan sosial di antara mereka, alat yang digunakan serta kontrol sosial yang dilakukan

Tulisan ini dikemas ulang dari hasil penelitian yang bersifat kualitatif. Menurut Moleong (2009:6), penelitian kualitatif adalah penelitian yang bermaksud memahami fenomena tentang apa yang dialami subjek penelitian, misalnya perilaku, persepsi, motivasi, tindakan, dan lainlain, secara holistik dan dengan cara deskriptif dalam bentuk kata-kata dan bahasa, serta pada suatu konteks khusus yang alamiah dan dengan memanfaatkan berbagai metode ilmiah. Penelitian kualitatif menekankan quality atau hal terpenting dari sifat suatu barang/jasa. Hal terpenting dari suatu barang atau jasa berupa kejadian/fenomena/gejala sosial adalah makna dibalik kejadian tersebut yang dapat dijadikan pelajaran berharga bagi pengembangan konsep teori. Jangan sampai sesuatu yang berharga tersebut berlalu tampa meninggalkan manfaat. Penelitian kualitatif diekplorasi dan diperdalam dari suatu fenomena sosial atau suatu lingkungan sosial yang terdiri atas perilaku, kejadian, tempat dan waktu (Satori dkk, 2009:22).

Proses pengumpulan serta pengolahan data dan informasi penelitian dilakukan dalam beberapa teknik, yaitu observasi, wawancara, rekam, studi kepustakaan, dan analisis data. Setelah 
itu, data primer berupa teks cerita ungkapan tradisional dianalisis dengan menggunakan pendekatan hermeneutik.

Menurut Ratna (2004:45), secara etimologis hermeneutik berasal dari kata hermeneuein, bahasa yunani, yang berarti menafsirkan atau menginterpretasikan. Secara mitologis, pendekatan ini dikaitkan dengan dengan Hermes, nama Dewa Yunani yang menyampaikan pesan ilahi kepada manusia. Pada dasarnya media pesan adalah bahasa, baik bahasa lisan maupun bahasa tulisan. Jadi, penafsiran disampaikan lewat bahasa, bukan bahasa itu sendiri. Teks sastra perlu ditafsirkan sebab di satu pihak ia terdiri atas bahasa, di pihak lain, di dalam bahasa sangat banyak makna yang tersembunyi, atau dengan sengaja disembunyikan. Hermeneutik berkaitan dengan upaya pemaknaan suatu analog teks; misalnya memahami organisasi atau kelompok sosial melalui pemaknaan cara lisan atau data tekstual. Pertanyaan mendasar adalah : apa arti dan makna teks itu?. Ini berarti, interpretasi adalah upaya untuk membuat jelas atau mebuat studi bermakna. Oleh sebab itu, objek mesti kajian mesti dalam bentuk teks atau analog teks yang sepintas terlihat kabur serta terkadang saling bertentangan. Interpretasi bermaksud agar yang tidak jelas menjadi jelas untuk bisa dipahami. Interpretasi mesti menjadi kerangka berfikir dalam usaha memperjelas pengertian tersembunyi menjadi sesuatu yang bermakna dan jelas (Moleong, 1989:2).

Pendekatan hermeneutik memandang teks sastra dan filsafat sebagai objek kajian yang seyogianya disejajarkan dengan pendekatan interpretasi, pemahaman, versthen dan retroaktif. Dalam ilmu-ilmu sosial juga disebut metode kualitatif, analisis isi, alamiah, naturalistik, studi kasus, etnografi, etnometodologi dan fenomenologi serta biasanya dipertentangkan dengan metode kuantitatif (Moleong, 1989).

Pendekatan hermeneutik dinilai tepat untuk digunakan dalam menganalisis teks ungkapan tradisional yang dimiliki secara kolektif oleh masyarakat Minangkabau, khususnya masyarakat Kecamatan Pasaman Kabupaten Pasaman Barat. Namun demikian, penggunaan hermeneutik tidak dimaksudkan untuk menghasilkan interpretasi yang bersifat paling benar. Kenyataannya adalah, setiap peneliti berpeluang memiliki bergerak dari langkah awal yang berbeda, sekaligus akan memandang objek tertentu melalui horoson dan paradigma yang berbeda.

\section{PEMBAHASAN}

\section{Sekilas Kecamatan Pasaman}

Pasaman merupakan nama dari salah satu kecamatan yang terdapat di Kabupaten Pasaman Barat Provinsi Sumatera Barat. Kabupaten Pasaman Barat sendiri merupakan salah satu dari 3 (tiga) kabupaten pemekaran di Provinsi Sumatera Barat, yaitu terbentuk berdasarkan Undangundang Nomor 38 Tahun 2003 tentang Pembentukan Kabupaten Dharmasraya, Solok Selatan dan Pasaman Barat. Batas administratif Kabupaten Pasaman Barat ; Sebelah Utara berbatasan dengan Kabupaten Mandailing Natal Sumatera Utara, sebelah Selatan berbatasan dengan Kabupaten Pasaman dan Kabupaten Agam Sumatera Barat, sebelah Barat berbatasan dengan Samudera Indonesia dan sebelah Timur berbatasan dengan Kabupaten Pasaman Sumatera Barat (BPS Kabupaten Pasaman Barat, 2017:15). 
Kecamatan Pasaman meliputi 3 (tiga) kenagarian yaitu :

1. Nagari Lingkuang Aua, meliputi 11 jorong yaitu : Jorong Pasaman Baru, Jorong Kampung Cubadak, Jorong Simpang Empat, Jorong Katimaha, Jorong Bandarejo, Jorong Padang Durian Hijau, Jorong Jambak, Jorong Rimbo Binuang, Jorong Batang Biyu, Jorong Tanjung Pangka, Jorong Ribo Canduang.

2. Nagari Aur Kuning, meliputi 6 jorong yaitu: Jorong Padang Tujuh, Jorong Pinagar, Jorong Suka Menanti, Jorong Lubuk Landur, Jorong Lembah Binuang, Jorong Bukik Nilam,

3. Nagari Aia Gadang, meliputi 3 jorong yaitu: Jorong Aia Gadang Barat, Jorong Aia Gadang Timur, Jorong Labuah Luruih. II (Kecamatan Pasaman dalam Angka, 2017:5).

\section{Analisis Ungkapan Tradisional : Membaca Karakteristik Masyarakat Pasaman Barat}

Ungkapan tradisional Minangkabau, hasil didokumentasi yang dilakukan di Kecamatan Pasaman Kabupaten Pasaman Barat adalah : (1) Ungkapan mandapek raso kailangan; (2) Ungkapan sairiang batuka jalan, sarupo balain sabuik; (3) Ungkapan jorong batakok tanun baguluang; (4) Ungkapan mamak bapisau tajam kamanakan balihia gantiang; dan (5) Ungkapan maampang ndak sampai ka subarang mandindiang ndak sampai ka langik. Berikut penjelasan karakteristik masyarakat Minangkabau yang direfleksikan ungkapan tradisional tersebut, sekaligus menjadi bagian dari kearifan lokal masyarakat Pasaman Barat secara umum:

\section{Mandapek Raso Kailangan}

\section{“Mandapek raso kailangan" "Mendapat rasa kehilangan" "Mendapat tapi merasa kehilangan"}

Hal pertama yang patut ditulis tentang ungkapan “mandapek raso kailangan” adalah, mengemukanya logika berpikir yang tidak lazim dari si pengguna ungkapan terkait dengan sesuatu (teks) yang diungkapkan dengan perasaan yang sedang dialami. Ketidaklaziman tersebut disebabkan oleh kenyataan berbeda atau bertolakbelakangnya yang disampaikan dengan kenyataan sesungguhnya yang dialami serta dirasakan oleh si pengguna ungkapan. Teks ini bercerita tentang rasa dan perasaan, sebagaimana dipahami oleh pengguna ungkapan, baik dialami sendiri maupun dialami oleh orang lain. Menurutnya, "rasa" semestinya senang dan bahagia karena mendapatkan sesuatu. Namun justru sebaliknya yang dialami, kecewa dan kegundahan justru lebih menjadi "rasa" yang ada.

Menurut pengguna ungkapan, dia atau seseorang yang lain sesungguhnya telah mendapatkan sesuatu, namun justru lebih merasakan adanya sesuatu yang hilang. Si pengguna ungkapan berhasil meraih sesuatu namun justru tidak merasa berbahagia terhadap keberhasilan tersebut. Kegagalan terasa lebih menguasai dirinya. Bersamaan dengan didapatkannya sesuatu kehilangan terasa lebih besar serta lebih dianggap berharga. Sehingga, apa-apa yang didapatkan menjadi tidak seimbang dengan hal-hal yang didapatkan. Tidak lazim memang, karena biasanya ketika seseorang memperoleh sesuatu maka dia akan merasa senang. Ketika seseorang meraih kesuksesan dalam hidup misalnya, maka tentu dia akan merasa bahagia. 
Rasa bahagia terhadap harta misalnya, yang dimiliki seseorang tentu akan bertambah ketika suatu hari dia membawa pulang sejumlah uang. Secara logika matematis dia bertambah kaya dan semestinya bertambah bahagia karena telah bertambahnya harta. Namun tidak demikian adanya, seseorang yang digambarkan oleh ungkapan"mandapek raso kailangan" justru merasa tidak bahagia. Dia justru merasa kehilangan yang lebih bernilai justru ketika berhasil menambah nominal kekayaannya. Secara karakter perasaan kecewa yang muncul justru ketika mendapatkan sesuatu tentunya memunculkan pertanyaan penting, sesungguhnya apa yang terjadi. Jawabannya adalah, seseorang itu memang berhasil menambah pundi-pundi uang, namun kehilangan sesuatu yang lebih berharga. Sesuatu yang dianggap lebih berharga tersebut bisa jadi berhbungan dengan hal-hal yang bersifat immateri, seperti harga diri dan kehormatan. Artinya, pada konteks ini jumlah uang yang berhasil diraih_pada satu sisi memperkuat status dalam hal kepemilikan harta, namun pada sisi lain menjadi penyebab hilangnya sesuatu yang sejatinya lebih berharga dan bernilai, yaitu harga diri dan martabat.

Pada kasus lain misalnya, suatu hari si pengguna ungkapan dipromosikan oleh atasannya untuk naik jabatan. Mengacu pada ungkapan, justru karena promosi tersebut dia mengalami kekecewaan yang dalam. Pertanyaan kembali muncul, apa sebenarnya yang terjadi dengan orang tersebut. Sementara dalam pandangan atasan dan semua orang yang mengetahui hal tersebut si pengguna ungkapan seharusnya merasa senang dan bahagia namun justru dirasakan sebaliknya oleh yang bersangkutan. Sekali lagi, aneh memang, menurut pengguna ungkapan promosi tersebut bukanlah sesuatu yang prestesius. Dia justru sedang mengalami kekecewaan yang mendalam. Penyebabnya kembali pada hal-hal yang bersifat immateri dan psikologis, karena bisa jadi bersama promosi jabatan tersebut dia justru akan kehilangan kebersamaan dengan keluarga yang dicintai. Promosi jabatan tersebut berkonsekuensi pada terpisahnya dia dengan isteri serta anak-anak yang sedang membutuhkan kebersamaan dan kasih sayang. Pada kasus ini, dia dipromosikan naik jabatan, namun secara bersamaan akan terpisah jauh dengan keluarga yang dikasihi. Dia dalam kasus ini telah "mandapek tapi maraso kahilangan".

Menurut Rajo Bingkalang (wawancara tanggal 14 Mei 2016), masyarakat Minangkabau di Nagari Aua Kuniang Pasaman Barat, memiliki bentuk kearifan yang unik serta berbeda dengan masyarakat dari sukubangsa lain dalam menginformasikan sesuatu yang dialami dan dirasakan. Salah satunya terbukti dengan adanya ungkapan "mandapek raso kailangan”. Masyarakat Pasaman Barat, khususnya para warga yang mendiami Nagari Aua Kuniang, memiliki kecenderungan untuk menggunakan logika berpikir terbalik-berpengaruh pada watak dan karakteristik masyarakatnya dalam menentukan pilihan terhadap hal-hal yang bersifat dilematis. Pilihan-pilihan tersebut ternyata berhubungan dengan perolehan hal-hal yang bersifat materi kebendaan, seperti harta, jabatan dan kedudukan dengan kehilangan hal-hal yang bersifat immateri psikologis sepeti harga diri dan martabat. Pada pilihan yang bersifat dilematis tersebut warga nagari ini sekaligus cenderung pula tampil dalam perbedaan karakteristik, sebagai dampak perasaan yang sedang dialamai, dengan apa yang sedang dipikirkan orang lain tentang dirinya.

Melalui ungkapan “mandapek raso kailangan” masyarakat Aua Kiniang Pasaman Barat sesungguhnya ingin menginformasikan perasaan terdalamnya yang sedang mengalami kekecewaan kepada orang lain. Perasaan itulah kebenaran yang sesungguhnya, meskipun secara kasat mata dia semestinya tampak berbahagia. Meskipun dalam kacamata orang banyak tidak 
demikian namun penggunaan ungkapan tersebut adalah jawaban sesungguhnya terhadap realitas psikologis yang dialami seseorang. Kenyataan ini sesungguhnya membuktikan bahwa tidak serta merta pandangan sosial berbanding lurus dengan kenyataan yang sebenarnya dialami oleh seseorang. Oleh karena itu, sebagai sebuah ungkapan tradisional, menurut maestro, ungkapan "mandapek raso kailangan" bisa digunakan sebagai alat komunikasi efektif dalam upaya menjelaskan realitas sejati psikologis seseorang. Pada konteks itu, si pengguna ungkapan sesungguhnya sedang berupaya mengurangi efek keterkejutan psikologis lawan bicara atas apa yang dia peroleh dan secara sekaligus atas apa yang dia rasakan dengan perolehan tersebut. Meskipun biasanya lawan bicara memahami upaya yang sedang ditempuh oleh pengguna ungkapan, namun itulah bentuk kearifan dalam berkomunikasi yang tengah mereka praktekkan secara bersama-sama-berpengaruh secara psikologi sosial dalam pembentukan karakter masyarakat ketika berkomunikasi dan berinteraksi.

Oleh karena itu, melalui ungkapan "mandapek raso kailangan" sebenarnya diajarkan satu bentuk kearifan dalam konteks berlangsungnya komunikasi dan interaksi sosial antara dua orang atau lebih di tengah masyarakat Kecamatan Pasaman. Paling tidak, melalui ungkapan tersebut diajarkan watak dan karakter yang tampak pada sikap yang cepat tanggap dengan kejadian yang menimpa orang lain serta perilaku terbaik yang mengikuti kejadian tersebut. Kemampuan dalam mengendalikan perasaan serta kecakapan dalam menyikapi setiap permasalahan yang muncul di tengah masyarakat, baik dalam konteks kehidupan pribadi mapun dalam konteks kepentingan sosial kemasyarakatan, menjadi pesan moral yang penting untuk dibaca ulang terkait dengan karakteristik masyarakat Minangkabau di Kecamatan Pasaman Kabupaten Pasaman Barat Sumatera Barat.

\section{Sairiang Batuka Jalan Sarupo Balain Sabuik}

\section{"Sairiang batuka jalan Sarupo balain sabuik" \\ "Seiring bertukar jalan serupa berlain sebut" "Seiring bertukar jalan serupa berlain sebutan"}

Ungkapan "sairiang batuka jalan dan sarupo balain sabuaik" secara umum menggambarkan bahwa kehidupan sosial budaya masyarakat Minangkabau, khususnya di Nagari Aua Kuniang Pasaman Barat, senantiasa diwarnai oleh dinamika, keberagaman dan perbedaan. Sebagaimana dijelaskan Rajo Bingkalang (wawancara tanggal 14 Mei 2016), sebagian aspek kehidupan masyarakat Pasaman Barat mengacu pada dua ungkapan ini. Melalui ungkapan ini terjelaskan satu fenomena sosial budaya yang dilakoni oleh para warganya yang menghargai kompromi dalam berdinamika serta menghormati perbedaan dalam keberagaman. Masyarakat Pasaman Barat menyadari bahwa dalam upaya mewujutkan harapan dan cita-cita bersama tersedia banyak jalan yang dapat ditempuh serta banyak cara yang dapat dilakukan. Oleh karena itu, menjadi bagian dari khasanah sosial budaya masyarakat Pasaman Barat, setiap individu memiliki peluang yang sama untuk berbuat maksimal dengan cara yang berbeda.

Mengacu pada nilai budaya Minangkabau sebagaimana terdapat pada ungkapan "sairiang batuka jalan dan sarupo balain sabuik" setiap individu anggota masyarakat diberi 
keleluasaan untuk memilih cara yang berbeda dalam berperan secara aktif sebagai warga masyarakat yang peduli sesama. Lebih dari itu, masyarakat Pasaman Barat juga memahami bahwa tidak ada paksaan untuk mereka "sama" dan "serupa" dalam banyak hal. Mereka bebas memilih jalan dan cara yang berbeda dalam sama-sama berbuat untuk kepentingan pribadi, keluarga dan sesama. Karaktersistik sosial yang dijelaskan oleh ungkapan ini terpatri pada kesadaran bahwa tanggung jawab mesti dipikul secara bersama-sama, meskipun berbeda metode serta teknik dalam menunaikan rasa tanggung jawab tersebut.

Kiranya, beragam dan berbedanya cara dan jalan yang dilakukan serta ditempuh tersebut sangat mungkin untuk dilakukan. Pertama, setiap individu bisa jadi lahir dan tumbuh dalam kultur keluarga yang berbeda. Di samping itu, sesuai dengan bidang kehidupan yang dipilih dan digeluti, bisa jadi pula setiap individu bertumbuh menjadi dewasa dengan mengenyam pendikan yang tidak sama. Pengalaman hidup yang berbeda, beban sosial ekonomi keluarga yang berbeda serta banyak hal lainnya yang berbeda serta kesemuanya sangat berpengaruh dalam pembentukan jati diri dan karakteristik dalam melihat kepentingan atas nama "bersama". Oleh karena itu, ketika semua mereka dituntut untuk berbuat dan ikut bertanggung jawab, meskipun untuk satu tujuan yang sama, sangat terbuka peluang mereka akan juga akan berbeda terkait dengan ide dan gagasan serta metode dan cara yang digunakan serta capaian target individual yang dipilih; muaranya adalah untuk kepentingan bersama.

"Sairiang batuka jalan dan sarupo balain sabuik" adalah sebuah keniscayaan. Segala perbedaan yang ada di tengah masyarakat sesungguhnya adalah potensi sosial budaya yang semestinya bisa diolah dan disikapi secara proporsioal. Segala perbedaan semestinya pula tidak memunculkan gesekan serta konflik sosial budaya di tengah masyarakat. Perbedaan sikap dan perilaku serta aneka ragam karakter merupakan wajah positif dari setiap kelompok masyarakat yang apabila dikelola secara baik dapat memunculkan energi kebaikan untuk kepentingan bersama. Sebaliknya, apabila perbedaan dan keanekaragaman tersebut tidak mampu dilihat serta dimaknai secara proporsional, maka akan banyak permasalahan yang muncul pada setiap kelompok masyarakat.

Demikian pula halnya untuk berbagai kelompok sosial berbeda akar budaya yang hidup berdampingan. Segala perbedaan dan keanekaragam yang mereka miliki sesungguhnya dapat menjadi jembatan silaturahmi yang dapat menghubungkan mereka untuk saling berbagi, saling melengkapi dan menyempurnakan. Menurut Rajo Bingkalang, poin-poin penting inilah yang menjadi pesan moral nilai budaya ungkapan "sairiang batuka jalan dan sarupo balain sabuaik". Sebagai nilai budaya ia mesti tertanam secara baik dalam setiap anggota masyarakat Pasaman Barat khususnya dan masyarakat Minangkabau di Sumatera Barat pada umumnya. Sebuah karakter sosial yang meyakini bahwa berbeda dan beraneka ragam adalah sebuah keniscayaan yang mesti diterima serta disikapi secara bijak guna mewujudkan kemaslahatan hidup bersama dalam satu kelompok sosial budaya masyarakat. 


\section{Jorong Batakok Tanun Baguluang}

\section{“Jorong batakok tanun baguluang" Jugalo pulang ka jugalo Jugalo latakan ditampaiknyo}

Secara implisit ungkapan "jorong batakok tanun baguluang, jugalo pulang ka jugalo, jugalo latakan ditampaiknyo" bermakna bahwa suatu pekerjaan mesti diserahkan pada ahlinya. Dengan kata lain, pengguna ungkapan tersebut berpesan bahwa bekerja dan berbuat harus sesuai dengan bidang dan keahlian. Jangan campuri urusan orang lain, bagilah pekerjaan untuk setiap orang secara adil dan proporsional. Menurut Masrul (anggota KAN Nagari Aia Gadang, wawancara tanggal 17 Mei 2016), beberapa pesan singkat ini merupakan nilai budaya Minangkabau yang terdapat pada tiga larik ungkapan "jorong batakok tanun baguluang, jugalo pulang ka jugalo, jugalo latakan ditampaiknyo. Beberapa pesan moral budaya Minangkabau tersebut sekaligus adalah karakter dan kepribadian yang mesti dimiliki oleh setiap anggota masyarakat Minangkabau dimanapun mereka berada.

Sebagai karakter dan kepribadian yang pada gilirannya akan dapat dicermati melalui sikap dan perilaku setiap orang, semestinya pula nilai budaya ungkapan "jorong batakok tanun baguluang, jugalo pulang ka jugalo, jugalo latakan ditampaiknyo" terus diajarkan kepada generasi muda melalui berbagai media pengajaran dan penanaman nilai yang bersifat "berterima" dengan selera zaman yang terus berubah. Para tokoh adat Nagari Aia Gadang Kecamatan Pasaman mesti menemukan metode dan cara yang tepat serta relevan untuk digunakan dalam mewariskan nilai budaya ungkapan tersebut. Kekeliruan dalam memilih cara penyampaian bisa jadi akan berdampak pada semakin jauhnya generasi Aia Gadang dengan ungkapan tersebut. Belum lagi soal kandungan nilai budaya yang terdapat pada ungkapan, mesti ditemukan formulasi yang tepat dalam mewariskannya kepada generasi muda. Kehendak zaman serta perubahan pola pikir generasi muda dalam memilah dan memilih media tertentu dalam upaya pembentukan karakter sangat dimungkinkan berbeda bahkan bertentangan dengan pola-pola lama yang diterapkan dalam masyarakat konvensional Nagari Aia Gadang.

Terutama pada masa lampau masyarakat Nagari Aia Gadang Pasaman Barat menggunakan ungkapan "jorong batakok tanun baguluang, jugalo pulang ka jugalo, jugalo latakan ditampaiknyo" sebagai nasehat dan peringatan. Bentuk nasehat dan peringatan yang ingin disampaikan melalui ungkapan tersebut biasanya berkaitan dengan keharusan bagi setiap orang untuk memilih bidang pekerjaan tertentu yang sesuai dengan bakat, kemampuan individual serta status sosial adat dan agama yang melekat pada diri seseorang. Secara eksplisit melalui ungkapan tersebut diajarkan bahwa seorang laki-laki sebaiknya tidak menggeluti bidang pekerjaan sebagaimana lazimnya dilakukan oleh kaum perempuan. Secara normatif jenis dan bidang pekerjaan yang melibatkan kaum laki-laki dan kaum perempuan sesungguhnya dibedakan menurut aturan adat. Selanjutnya, dalam struktur sosial budaya, sesungguhnya terdapat norma dan aturan yang memberikan batasan bahwa jenis pekerjaan tertentu hanya dibebankan kepada kalangan tertentu pula. Mengacu pada struktur tersebut para ninik mamak (penghulu), para ulama, kalangan cerdik pandai, pemuda, kaum perempuan, dan anak-anak memiliki beban dan 
jenis pekerjaan yang berbeda. Ketaatan terhadap norma dan aturan yang sejatinya bersifat mengikat setiap unsur dalam struktur sosial adat tersebut sesungguhnya menghendaki adanya keteraturan dalam berbagai bidang kerja.

Bahkan maestro mencontohkan secara gamblang bahwa dalam struktur sosial sejenis semisal ulama, apabila berstatus khatib (ulama) maka jangan memaksakan diri untuk berperan selaku imam (ulama) dalam shalat berjamaah. Seorang bergelar khatib sayogianya mengambil tugas sebagai khatib serta konsisten dalam tugas tersebut. Sebaliknya, seseorang yang berstatus sosial keagamaan sebagai imam jangan pula melempar tanggung jawab, memberikan tugas sebagai imam shalat serta kepada ulama yang bergelar khatib. Apabila seseorang yang bergelar khatib memaksakan diri menjadi imam shalat dan seorang imam melempar tanggung jawab sehingga menghendaki tugasnya diemban oleh seorang khatib, maka jamaah akan kehilangan pedoman dalam mengikuti penunjuk arah untuk mencapai keikhlasan dalam beribadah. Demikian pula dalam struktur sosial adat yang lain, seorang penghulu bergelar datuk jangan berlepas tangan dari tanggung jawabnya sebagai pengayom anggota kaum, sehingga anggota kaum yang hanya bergelar "sutan" atau "sidi" terpaksa mengambil peran tugas seorang penghulu.

Isyarat penting yang patut disimak berdasarkan contoh sederhana yang diberikan maestro adalah, pentingnya sikap profesional dan bertanggung jawab dalam berbuat berdasarkan bidang keahlian sekaligus berdasarkan status sosial agama dan adat yang melekat pada diri seseorang. Isyarat ini tentunya layak untuk direnungkan serta diimplementasikan dalam praktik kehidupan bermasyarakat. Setiap anggota masyarakat dituntut untuk berperan aktif dalam berbagai bidang pekerjaan. Oleh karena itu, hal pertama yang mesti disadari adalah, mereka mengenal setiap kelemahan dan kelebihan yang dimiliki, serta dengan lapang dada mengakui kelemahan dan kelebihan yang ada pada orang lain. Selanjutnya setiap anggota masyarakat dalam struktur sosial adat dan agama juga menyadari peran dan tanggung jawabnya berdasarkan status tersebut, yang secara normatif sesunggunhnya telah diatur dalam ajaran adat dan agama.

Mesti tertanam dalam diri setiap anggota masyarakat keinginan serta kesadaran untuk berbuat berdasarkan potensi dan kompetensi yang dimiliki. Menerima dengan ikhlas bidang pekerjaan tertentu untuk dikerjakan oleh orang lain sesuai dengan status sosial adat dan agama orang tersebut sekaligus menjadi wujud dari kepekaan karakter yang harus terus dipupuk dan dipertahankan. Pada setiap bidang pekerjaan selalu ada orang-orang yang berkompeten untuk mengerjakannya. Menurut maestro, apabila pola pembagian kerja berdasarkan bidang keahlian tersebut berhasil maka ketika itulah nilai budaya ungkapan "jorong batakok tanun baguluang, jugalo pulang ka jugalo, jugalo latakan ditampaiknyo" telah terealisasi dalam kehidupan satu kelompok masyarakat secara nyata. Menjadikan tanggung jawab sebagai karakter dan kepedulian untuk ikut berbuat sebagai kepribadian merupakan prasyarat penting berjalannya roda kehidupan sosial budaya yang harmoni dalam beraneka ragam budaya, sekaligus dalam berbedanya stutus sosial budaya setiap anggota masyarakat di Minangkabau.

\section{Mamak Bapisau Tajam Kamanakan Balihia Gantiang}

"Mamak bapisau tajam kamanakan balihia gantiang"

"Mamak berpisau tajam kemenakan berleher genting"

"Mamak memiliki pisau tajam kemenakan memiliki leher genting" 
Menurut Khidir (Ketua KAN Nagari Lingkuang Aua, wawancara tanggal 15 Mei 2016), ungkapan "mamak bapisau tajam, kamanakan balihia gantiang”, biasa digunakan oleh masyarakat Nagari Lingkuang Aua Pasaman Barat terkait dengan fungsi dan kewenangan yang dimiliki oleh seorang mamak pada satu pihak dan kemenakan pada pihak lain. Biasanya, ungkapan tersebut muncul dalam konteks hubungan mamak dan kemenakan dalam satu kaum, misalnya dalam upaya menyelesaikan sebuah permasalahan. Sesuai dengan fungsi dan kewenangan yang dimiliki, tentunya beban tanggung jawab yang dipikul oleh seorang mamak berbeda dengan beban yang ada pada kemenakan. Meskipun permasalahan yang tengah dihadapi berkaitan secara langsung dengan kehidupan pribadi kemenakan, atau secara lebih luas berkenaan dengan kepentingan anggota satu kaum, tetap saja beban tanggung jawab lebih besar berada dipundak seorang mamak. Pada konteks itu, peran mamak bukan saja sebagai pengayom dan pelindung, namun juga sebagai titik sentral dalam upaya melahirkan keputusan serta kebijakan.

Di Nagari Lingkuang Aua Pasaman Barat khususnya, sesuai dengan status sosial adat yang dimiliki, seorang mamak memiliki kewenangan untuk mengambil keputusan. Pada satu sisi seorang mamak dibebankan "keharusan" untuk menerima setiap masukan yang diberikan oleh kemenakan, namun pada sisi lain sekaligus memiliki kewenangan untuk menolak usulan tersebut sama sekali. Penerimaan atau justru sebaliknya penolakan yang dilakukan oleh mamak terhadap usulan serta masukan kemenakan diatur dalam tatanan nilai yang sebagian besanya memang tidak bersifat tertulis. Secara konseptual norma dan aturan yang bersifat mengikat pola hubungan antara mamak dan kemenakan tersebut telah terpatri dalam memori kolektif masyarakat Minangkabau secara umum, termasuk masyarakat Minangkabau di Pasaman Barat. Menurut maestro, merujuk pada status seseorang yang berkapasitas sebagai kemenakan, maka fungsi dan tanggung jawabnya adalah sebagai perencana dan penyampai. Sebaliknya, seorang mamak memiliki keleluasaan untuk membuat keputusan, meskipun tentu tetap dengan mempertimbangkan berbagai penyampaian dan rencana yang telah disiapkan oleh kemenakan.

Para kemenakan memiliki ruang untuk merencanakan atau membuat rumusan terkait langkah-langkah yang mungkin untuk ditempuh, menyampaikan pandangan serta memberikan masukan, namun kewenangan untuk memutuskan tetap berada di tangan mamak. Karena itulah, menurut maestro, ungkapannya berbunyi “mamak bapisau tajam, kamanakan balihia gantiang”. Kata "bapisau tajam" dalam ungkapan tersebut bermakna bahwa seorang mamak mempunyai hak serta kewenangan dalam mengambil keputusan. Sebaliknya, kata "balihia gantiang" dalam ungkapan bermakna bahwa seorang kemenakan terkondisi sebagai pihak yang mesti siap dalam menjalankan keputusan tersebut. Artinya, dalam konteks situasi darurat yang sedang dialami oleh seorang kemenakan (balihia gantiang), tidak bersifat menghilangkan kewenangan seorang mamak sebagai pengambil keputusan (bapisau tajam).

Sebagai pucuk pimpinan dalam suku/kaum ninik mamak adalah figur yang berhak untuk dihormati serta memiliki kewenangan dalam mengambil keputusan. Namun demikian, tentu saja setiap keputusan yang dikeluarkan oleh seorang mamak telah berdasarkan pada pertimbangan yang matang. Di samping itu, keputusan tersebut diambil setelah mendengar berbagai masukan dan pandangan yang diberikan oleh kemenakan atau anggota kaum/suku. Artinya, keputusan yang dikeluarkan oleh seorang mamak merupakan pilihan terbaik atas berbagai pertimbangan yang bersifat mengedepankan kemaslahatan setiap kemenakan atau 
anggota suku/kaum. Oleh karena itu, secara normatif upaya menempatkan seorang mamak sesuai dengan fungsi dan kewenangan yang dimiliki, merupakan pilihan bijak dalam mewujudkan tatanan kehidupan anak dan kemenakan yang lebih baik. Karakter sebagai pengambil keputusan yang dimiliki oleh seorang mamak serta penerimaan secara lapang dada oleh kemenakan atau anggota suku/kaum atas keputusan tersebut kiranya menjadi pesan nilai budaya yang diisyaratkan oleh ungkapan "mamak bapisau tajam kamanakan balihia gantiang”.

Sebagaimana dimaklumi, pada sebuah suku/kaum kemenakan merupakan banyak sabyek yang juga dituntut agar mengambil peran secara bijak dan proporsional. Oleh karena itu, setiap kemenakan mesti berupaya secara maksimal dalam tahap perencanaan, meskipun kemudian keputusan tetap berada di tangan mamak. Setiap kemenakan tidak boleh berputus asa dalam mengupayakan jalan terbaik dalam menyikapi setiap permasalahan mereka. Perencanaan demi perencanaan yang dirumuskan oleh anggota suatu kaum merupakan pernak-pernik kecerdasan kolektif yang mesti tetap tersampaikan kepada seorang mamak kaum. Oleh karena itu, anggota kaum/suku tidak hanya bersifat menunggu keputusan yang dikeluarkan oleh mamak kaum/ suku mereka. Meskipun "balihia gantiang” setiap kemenakan adalah sabyek pemilik ide dan gagasan yang harus menyiapkan banyak alternatif penyelesaian permasalahan. Peran aktif setiap kemenakan dalam satu kaum/suku dalam tahap perencanaan, memberi usulan dan pandanganpandangan alternatif, merupakan energi positiv untuk lahirnya keputusan yang bijak dan adil dari para mamak kaum. Karakter "kepemimpinan mamak" serta "keterpimpinan kemenakan" sebagaimana terdapat dalam ungkapan "mamak bapisau tajam, kamanakan balihia gantiang”, sekaligus menjadi khasanah nilai budaya Minangkabau khususnya masyarakat Minang di Pasaman Barat.

Mampu bersikap dan bertindak secara proporsional serta tidak melampaui batasan fungsi dan kewenangan sebagaimana diatur dalam norma adat merupakan prasyarat penting terjaganya pola hubungan antara mamak dan kemenakan serta antara para ninik mamak dengan anggota suku/kaum secara baik. Sehingga, ungkapan "mamak bapisau tajam kamanakan balihia ganting”, salah satu ungkapan tradisional Minangkabau yang tentunya tidak saja diapresiasi oleh masyarakat adat Nagari Lingkuang Aua Kecamatan Pasaman Pasaman Barat, menjadi karakter masyarakat Minangkabau secaa keseluruhan. Karakter nilai budaya yang penting dijadikan sebagai tolak ukur dalam upaya pengejawantahan fungsi dan peran berdasarkan kewenangan yang dimilki oleh mamak, ninik mamak, kemenakan dan anggota suku/kaum. Pesan moral nilai budaya ungkapan tersebut harusnya pula dapat diinternalisasi dalam sistem sosial budaya masayarakat Minangkabau secara luas. Setiap anggota masyarakat dapat berperan secara bertanggung jawab berdasarkan kemampuan yang dimilki, segaligus berdasarkan kewenangan yang ada pada masing-masing mereka.

\title{
Maampang Ndak Sampai ka Subarang Mandindiang Ndak Sampai ka Langik
}

\author{
“Maampang ndak sampai ka subarang, mandindiang ndak sampai ka langik" \\ "Menghambat tidak sampai ke seberang, mendinding tidak sampai ke langit" \\ "Menghalangi tidak sampai ke seberang, mendinding tidak sampai ke langit"
}


Menurut S. Dt. Rangkayo Basa (anggota KAN Nagari Aua Kuniang, wawancara tanggal 16 Mei 2016), ungkapan “maampang ndak sampai kasubarang, mandindiang ndak sampai ka langik”, terutama terkait penggunaannya, ditemukan misalnya ketika berlangsung berbagai bentuk kegiatan sosial masyarakat Minangkabau bernuansa adat, seperti pada acara peresmian gelar penghulu, terdengar dituturkan oleh seseorang yang sedang berpidato meresmikan gelar penghulu (malewakan gala), atau pada saat dialog yang melibatkan beberapa orang sertaberlangsung pada acara adat tertentu yang lazim dikenal dengan istilah "pasambahan adaik". Terkhusus pada dialog yang melibatkan beberapa orang ini, misalnya pada acara prosesi perkawinan, ungkapan "maampang ndak sampai kasubarang, mandindiang ndak sampai ka langik", bisa jadi dituturkan oleh satu orang saja namun adakalanya dituturkan oleh semua mereka yang terlibat dalam dialog, tergantung substansi pembicaraan yang sedang didialogkan.

Biasanya, pada berbagai bentuk kegiatan seremonial masyarakat Minangkabau bernuansa adat tersebut, ungkapan "maampang ndak sampai kasubarang, mandindiang ndak sampai ka langik" dituturkan oleh para juru runding yang lihai. Teks ungkapan muncul bersamaan dengan mengalir indahnya teks-teks lisan berbahasa Minangkabau serta terklasifikasi ke dalam bahasa Minangkabau Ragam adat. Penggunaan ungkapan tersebut muncul secara spontan namun didukung oleh konteks pembicaraan atau konteks dialog yang relevan. Di tengah masyarakat pun demikian, penutur ungkapan merupakan anggota masyarakat yang terkelompok pada kelompok ninik mamak, cerdik pandai, dan alim ulama. Ketiga kelompok masyarakat ini biasa disebut dengan tungku tigo sajarangan. Meskipun demikian, perlu digarisbawahi bahwa tidak semua orang yang tergabung ke dalam tiga kelompok elit masyarakat Minangkabau tersebut memahami secara baik makna yang tersirat dalam ungkapan. Minimal mereka tidak dalam tingkat pemahaman yang sama, meskipun sama-sama mampu menuturkan ungkapan.

Ungkapan “maampang ndak sampai kasubarang mandindiang ndak sampai ka langik” tentunya juga diapresiasi oleh masyarakat Minangkabau di Pasaman Barat. Sebagian dari anggota kelompok yang tergabung dalam unsur tungku tigo sajarangan juga memahami makna yang tersirat dari ungkapan tersebut secara baik dan komprehensif. Menurut maestro, bahkan masyarakat Pasaman Barat tidak saja menggunakan ungkapan ini pada saat berlangsungnya acara-acara kemasyarakatan bernuansa adat. Dalam keseharian masyarakat Pasaman Barat tidak jarang justru ungkapan ini dipakai disaat berlangsungnya dialog antara dua orang tokoh masyarakat atau lebih, meskipun tidak dalam konteks pembicaraan resmi. Anggota masyarakat yang secara sosial tidak terkelompok ke dalam struktur tungku tigo sajarangan pun relatif sering menggunakan ungkapan tersebut. Artinya, secara sosial budaya masyarakat Minangkabau di Pasaman Barat dekat dengan ungkapan tersebut, baik dalam aspek tutur maupun dalam aspek pemahaman terhadap ungkapan.

Maestro mengakui bahwa ungkapan "maampang ndak sampai kasubarang mandindiang ndak sampai ka langik” lebih merupakan bahasa lisan yang "dimiliki” oleh para tokoh adat, baik dalam kelompok ninik mamak, alim ulama atau cerdik pandai. Sehingga, bagi para tokoh masyarakat yang berasal dari tiga kelompok elit sosial masyarakat Minangkabau tersebut, ungkapan dimaksud telah menjadi ungkapan yang lazim digunakan dalam keseharian. Kenyataan tersebut sekaligus membuktikan bahwa tidak semua kalangan yang memahami nilai budaya Minangkabau sebagaimana terdapat pada dua kalimat ungkapan dimaksud, terutama kalangan 
generasi muda. Sebagian besar generasi muda dianggap "awam" dengan ungkapan"maampang ndak sampai kasubarang, mandindiang ndak sampai ka langik". Kenyataan tersebut tentunya berpengaruh dalam pembentukan karakter generasi muda, terutama dalam aspek tidak terinternalisasinya nilai budaya Minangkabau sebagaimana diisyaratkan oleh ungkapan dalam karakter kepribadian mereka.

Penggunaan ungkapan "maampang ndak sampai kasubarang mandindiang ndak sampai ka langik" dapat menjelaskan bahwa masyarakat Minangkabau di Pasaman Barat, misalnya tokoh masyarakat dari kalangan mamak (ninik mamak), memiliki kesadaran yang baik serta kearifan untuk terus berupaya mendewasakan pola pikir generasi muda (kemenakan). Meskipun sebaliknya, generasi muda (kemenakan) kurang memiliki minat untuk dekat dengan ungkapan tersebut, terutama disebabkan oleh pengaruh ilmu pengetahuan dan teknologi yang berdampak pada terjadinya perubahan selera zaman. Selanjutnya, ungkapan "maampang ndak sampai kasubarang" yang secara etimologis diterjemahkan menjadi "menghambat tidak sampai keseberang" mengisyaratkan bentuk sikap yang ditunjukkan oleh seorang ulama misalnya dalam menyikapi persoalan yang sedang dihadapi oleh umat. Pada konteks ini para ulama biasanya menawarkan berbagai solusi alternatif yang dimungkinkan untuk dipilih salah satunya oleh jamaah (umat) dalam menyikapi persoalan keagamaan yang dihadapi.

Tokoh masyarakat yang terkelompok dalam struktur tungku tigo sajarangan di Pasaman Barat, dengan mengamalkan nilai budaya ungkapan "maampang ndak sampai kasubarang mandindiang ndak sampai ka langik", memilih untuk tidak bersifat arogan dalam memutus setiap persoalan yang muncul dalam konteks hubungan sosial masyarakat. Meskipun berdasarkan norma dan aturan adat serta agama mereka memiliki hak dan kewenangan, namun tetap saja mereka membuka ruang dialog serta secara bijak memberi pilihan alternatif yang menempatkan masyarakat sebagai pihak yang mesti ikut berperan secara aktif dalam upaya melahirkan satu keputusan.

Sebagai suatu karakteristik secara eksplisist maestro mencontohkan, misalnya seorang mamak mesti segera mengambil keputusan berkenaan dengan permasalahan yang dihadapi oleh kemenakannya. Disertai oleh penjelasan dan argumentasi yang kuat si mamak telah mengemukakan pandangan sekaligus mengarahkan si kemenakan untuk memutuskan secara cepat, misalnya terkait dengan calon pendamping hidup. Pada konteks itu, si mamak telah memberi pandangan serta arahan agar si kemenakan memilih si A sebagai pendamping hidup, tentunya setelah mempertimbangkan banyak aspek. Si mamak, terutama dalam mengamalkan prinsip nilai budaya sebagaimana terdapat pada ungkapan "maampang ndak sampai kasubarang mandindiang ndak sampai ka langik" ternyata tetap membuka ruang dialog serta memberi keleluasaan bagi si kemenakan untuk tidak memilih si A. Si kemenakan tetap diberi hak untuk mengambil keputusan lain, tentunya apabila keputusan tersebut dilandaskan pada pertimbanganpertimbangan yang logis. Kalaupun si kemenakan tidak memilih si A sebagai calon pendamping hidup dan memilih si B serta tidak didasari oleh pertimbangan yang matang, maka biasanya si mamak akan tetap memilih sikap berkompromi dengan pilihan tersebut. Artinya, pada konteks silang pendapat tersebut si mamak memilih untuk tidak memaksakan kehendak dan keputusan, meskipun tentu dilakukan dengan berat hati. 
Pada gilirannya, apabila si kemenakan tetap dengan keputusannya-lebih memilih si B sebagai calon pendamping hidup dan bukan si A sebagaimana disarankan, maka si mamak akan mengikut demi menghindarkan terjadinya konflik secara berkelanjutan. Demi menyelamatkan kepentingan yang lebih luas si mamak memilih untuk mengalah serta berpegang pada prinsip nilai sebagaimana diajarkan oleh ungkapan "maampang ndak sampai kasubarang mandindiang ndak sampai ka langik”. Berkenaan dengan ungkapan ini posisi mamak menjadi jelas bahwa dia tidak setuju dengan keputusan si kemenakan serta mengkhawatirkan berbagai dampak yang tidak baik apabila keputusan terebut dipaksakan. Namun demikian, karena memikirkan kepentingan yang lebih luas, melibatkan banyak pihak, berpikir jauh ke depan serta mempertimbangkan bahwa pada akhirnya yang paling akan menerima dampak baik atau buruk keputusan tersebut adalah si kemenakan, si mamak bersikap toleran serta tetap memberi ruang bagi si kemenakan untuk berjalan sesuai dengan keputusannya. Si mamak yang bijak telah mengamalkan prinsip nilai budaya Minangkabau, "ndak maampang sampai ka subarang” dan "ndak mandindiang sampai ka langik”.

\section{PENUTUP}

Simpulan tulisan ini sebagai berikut: Pertama, ungkapan tradisional yang dibahas dalam kaitan menjelaskan karakteristik masyarakat Kecamatan Pasaman Kabupaten Pasaman Barat adalah : (1) Ungkapan mandapek raso kailangan; (2) Ungkapan sairiang batuka jalan sarupo balain sabuik; (3) Ungkapan jorong batakok tanun baguluang; (4) Ungkapan mamak bapisau tajam kamanakan balihia gantiang; dan (5) Ungkapan maampang ndak sampai ka subarang mandindiang ndak sampai ka langik. Kedua, melalui pendekatan hermeneutik disimpulkan bahwa kelima ungkapan berbicara tentang berbagai karakteristik masyarakat Minangkabau di Pasaman Barat, di antaranya responsif, menghargai perbedaan, profesional, bertanggung jawab, proporsional, berpikir jauh ke depan serta toleran.

Disarankan pentingnya kajian lanjutan terhadap ungkapan tradisional Minangkabau di Kabupaten Pasaman Barat, secara khusus dilakukan pada masyarakat pada 9 (sembilan) kecamatan lainnya di kabupaten ini. Kajian yang bersifat berkelanjutan seta dilakukan dengan pendekatan keilmuan yang relevan dinilai sebagai upaya antisipatif sekaligus strategis mengantisipasi agar tidak terkondisinya ungkapan tradisional dimaksud menuju kepunahan. 


\section{DAFTAR PUSTAKA}

BPS Kabupaten Pasaman Barat. 2017. Kabupaten Pasaman dalam Angka. Pemerintah Daerah Kabupaten Pasaman Barat.

Badan Pusat Statistik, Pasaman Barat Dalam AngkaTahun 2005. Padang: BPS, 1999.

Hadi, Abdul, dkk. Strategi Pembangunan Karakter dan Pekerti Bangsa. Kementerian Kebudayaan dan Pariwisata Republik Indonesia : Direktorat Pembangunan Karakter dan Pekerti Bangsa Direktorat Jenderal Nilai Budya, Seni dan Film.

BPS Kabupaten Pasaman Barat. 2017. Kecamatan Pasaman dalam Angka. Pemerintah Daerah Kabuapten Pasaman Barat

Moleong. 2009. Metodologi Penelitian Kualitatif. Bandung: PT Remaja Rosdakarya.

Ratna, Nyoman Kutha. 2004. Teori, Metode, dan Teknik Penelitian Sastra. Yokyakarta : Pustaka Pelajar.

Sibarani, R. 2002. Hakikat Bahasa. Bandung: PT Citra Aditya Bakti.

Satori, Djam'an dkk. 2009. Metodologi Penelitian Kualitatif. Bandung: Alvabeta. 